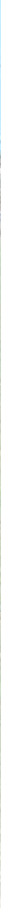

Schmidt László

\title{
A német Pz. IV-es Jagdpanzer vadászpáncélosok
}

A zok az eredmények, amelyeket a rohamlövegekkel felszerelt német alakulatok az 1939-41-ig terjedő időszakban az ellenséges páncélosokkal vívott harcokban elértek, valamint a német ipar törekvése arra, hogy lehetőség szerint csak egyfajta páncélteknőt kelljen gyártani, együttesen vezetett ahhoz, hogy a Heereswaffenamt (Hadsereg Fegyverzetügyi Hivatala) megbízást adjon a Jagdpanzer IV-es páncélos kifejlesztésére.

A háborús események 1939-től történő megindulásával Európa lengyel, nyugat- és dél-európai hadszínterein a német harckocsik tűzereje tökéletesen elegendőnek bizonyult. Az ellenséges páncélosok elleni harcban alkalmazott vontatott, vagy járművekre szerelt lövegek is megfeleltek az elvárásoknak. Ezeken a harctereken nem jelentett elviselhetetlen hátrányt, hogy a vontatott lövegek le- és felcsatolása idő- és munkaigényes volt. Még az is kezelhető problémát jelentett, hogy az improvizált „önjáró lövegek” az ellenséges tűz ellen személyzetüknek nem, vagy csak korlátozott mértékben nyújtottak védelmet.

Számtalanszor emlegetett módon, a német hadsereg számára drasztikus változást 1941-től a keleti fronton nemcsak az ott fellépő erős páncélzatú és tűzerejű szovjet harckocsik okoztak, de az ellenállás addig még nem ismert szívóssága is.

Itt már számított, hogy mennyi idő alatt tehető tűzkésszé egy löveg, vagy, hogy egy tüzelőállás változtatást milyen gyorsan képes végrehajtani a kezelőszemélyzet.

A német eszközök tekintetében a nehéz helyzeten javítani akaró, páncélvadásznak nevezett, de valójában csak önjáróvá tett lövegek, a Pz.Jg.I., a Marder II., a Marder III. - különösen a két utóbbi 75 mm-es lövegeikkel - már alkalmasak lettek volna a feladat ellátására, azonban felépítményeik gyenge páncélzata a személyzet számára csak kézifegyverek és kisebb repeszek ellen nyújtott valamennyi védelmet.

A harcot ezért inkább lesből, vagy mozgékonyságukat kihasználva kezdtek. Az ezekkel a lövegekkel felszerelt páncélvadász-zászlóaljak feladata elsődlegesen a gyalogság támogatása volt.

Az ilyen jellegü együttműködésben kiemelkedően szerepeltek az akkor újnak számító német StuG. III-as rohamlövegek. A korai változatoknál $75 \mathrm{~mm}$-es, de még rövid (L/24-es) csövű, kisebb torkolati energiájú lövegeikkel is a konstrukció sikerességét bizonyították.
ÖSSZEFOGLALÁS: A német Pz IV Jagdpanzer vadászpáncélos felépítményét egy $\mathrm{Pz}$ IV $\mathrm{F}$ harckocsi páncélteknőjére építették. A fő fegyverzetet a Rheinmetal cég által kifejlesztett, L/48 csőhosszúságú Panzerjägerkanone 39 (Pjk 39) képezte, amely később a Pak 39 megjelölést kapta. Az L/48-as löveg torkolati sebessége az alkalmazott lőszertől függően 930-450 m/mp volt. A Pz IV-es teknőjének, valamint a $75 \mathrm{~mm}$-es L/70 páncéltörő lövegnek a felhasználásával készült egy harmadik páncélvadász változat is, a Jagdpanzer IV L/70 (A).

KULCSSZAVAK: II. világháború, német haderő, vadászpáncélos, Pz. IV Jagdpanzer
ABSTRACT: The superstructure of the German Pz IV Jagdpanzer tank destroyer was built up on the chassis of the Panzer IV tank. The Panzeriägerkanone 39 (Pjk 39) with L/48 barrel length developed by the Rheinmetal company was its main armament, which had the marking Pak 39 later. The muzzle velocity of the $L / 48$ gun varied in the range $930-450 \mathrm{~m} / \mathrm{min}$ depending on the ammunition used. Using the Pz IV chassis and the $75 \mathrm{~mm} \mathrm{L/70}$ anti-tank gun, a third tank destroyer variant named Jagdpanzer IV L/70 (A) was also built.

KEY WORDS: World War II, German military force, tank destroyer, Pz. IV Jagdpanzer 


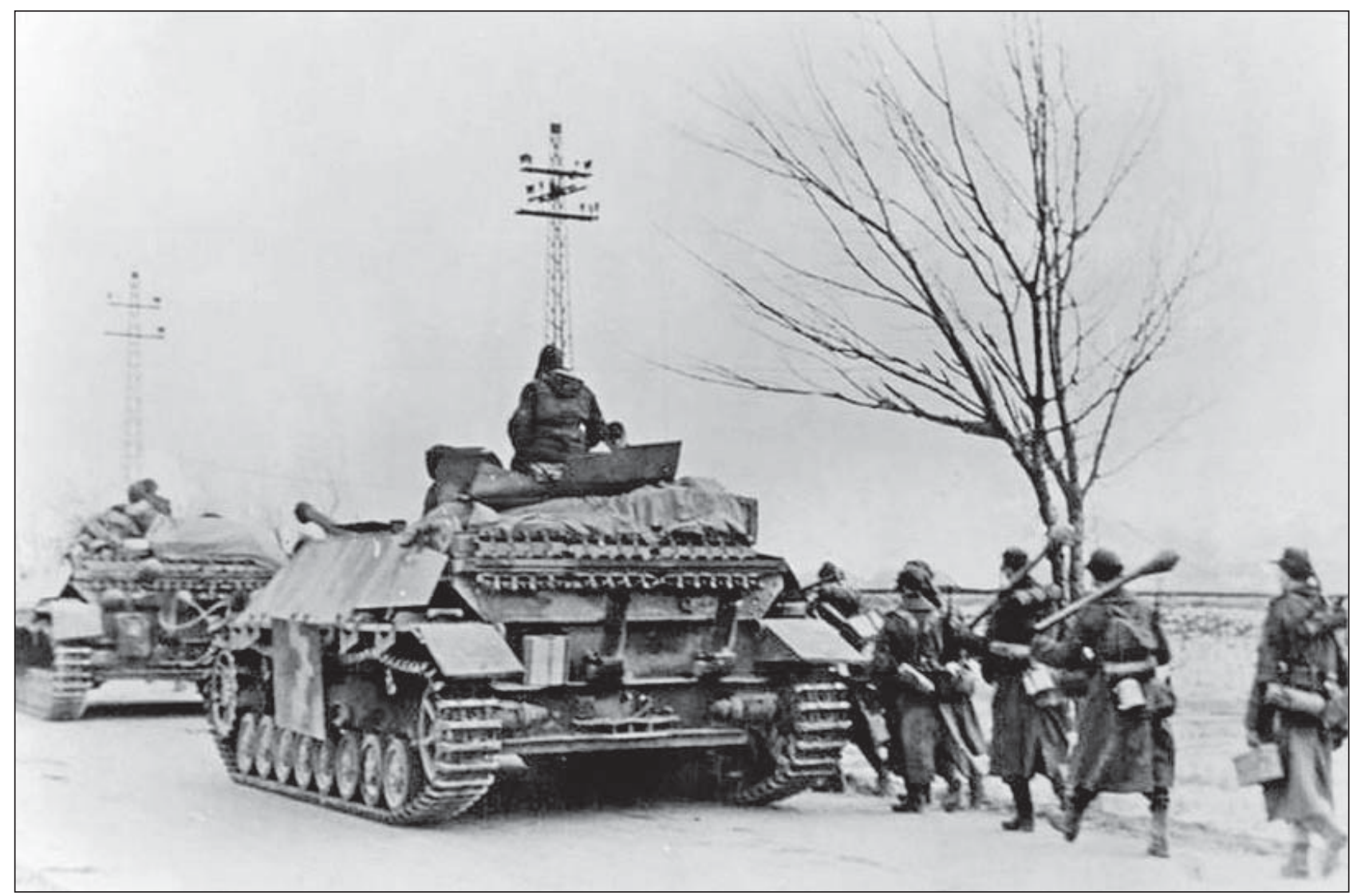

\section{2. ábra. A keleti fronton harcoló páncélvadász 1944/45 telén, kísérő gyalogsággal}

Mindezek nyomán kezdeményezte a Heereswaffenamt (Hadsereg Fegyverzetügyi Hivatala) egy „újfajta rohamlöveg" kifejlesztését.

A munkák 1942 szeptemberében indultak meg a plaueni Vogtländische Maschinenfabrik AG-nál. Az első, fából készült felépítményt egy Pz IVF harckocsi komplett és változatlanul hagyott páncélteknőjére építették. Ez a modell 1700 mm-es magasságával a StuG III-as rohamlövegnél 450, a Pz IV-es harckocsinál 980 mm-rel volt alacsonyabb.

A bemutatása során és azt követően, az elhangzott vélemények alapján, a tervezeten számtalan változtatást hajtottak végre. Módosították a homlokpáncélzat tervezett dőlésszögét és vastagságát is. Az első, még csak vasból készült változat szemléjére 1943 októberében került sor. Ennek és a néhány első példánynak jellegzetessége volt a

3. ábra. A vadászpáncélos két első változatának páncélvastagságai és azok dölésszögei

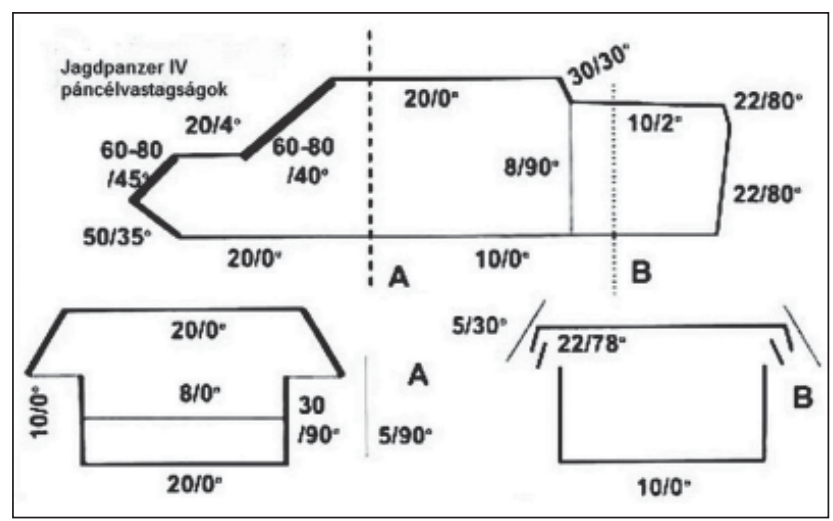

felépítmény oldal- és homlokpáncéljainak íves átmenete, amelyet később gyártástechnikai okokból megváltoztattak. A homlokpáncélon a löveg jobb és bal oldalán egy-egy kúpos fedéllel lezárható géppuska-nyílás volt. A két oldalsó páncéllemezen is volt kisebb, közelharcra alkalmazható géppisztoly-nyílás, amely már a próbák során sem bizonyult célszerűnek. A későbbi példányokon először behegesztették, majd teljesen elhagyták.

A fő fegyverzetet a Rheinmetal cég által kifejlesztett, L/48 csőhosszúságú Panzerjägerkanone 39 (Pjk 39) képez-

4. ábra. A rajz az eredeti Pz IV-es görgös kocsijától eltérő, két első erősített változatot szemlélteti

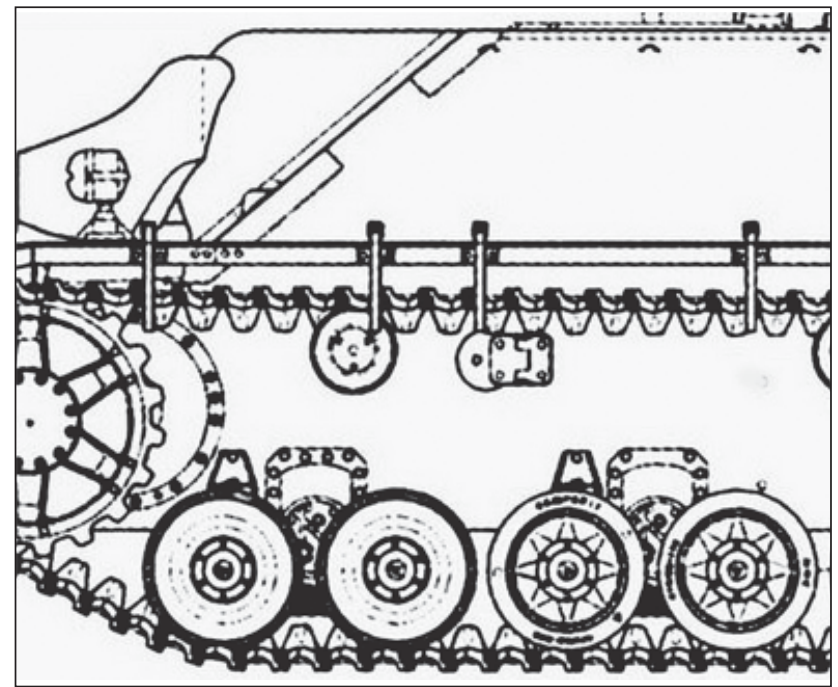




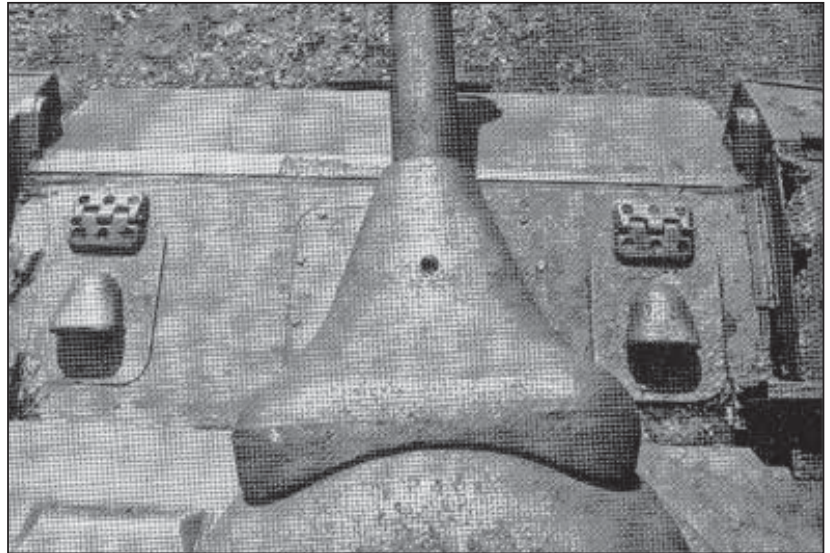

5. ábra. A rendkívül kedvező kialakítású lövegblende felülnézetból

te, amely később a Pak 39 megjelölést kapta. A harckocsi középvonalától $200 \mathrm{~mm}$-rel jobbra eltolt teljes löveget, egy kerettel együtt kardán felfüggesztéssel építették a páncélosba, amelynek lövegblendéjét kívül két, ballisztikailag nagyon kedvező kialakítású öntöttacél burkolat védte. $A z$ egyesített lőszer használata 10-15 lövés/min tűzgyorsaságot tett lehetővé. A tüzmagasság $1400 \mathrm{~mm}$ volt, a löveggel jobbra $15^{\circ}$, balra $12^{\circ}$-os, függőlegesen $-8-+15^{\circ}$ szögtartományban lehetett irányozni.

Az L/48-as löveg torkolati sebessége az alkalmazott lőszertől függően $930-450 \mathrm{~m} / \mathrm{sec}$ volt. A 7,5 cm Pzgr 39 jelü páncélgránát $100 \mathrm{~m}$ távolságból $106 \mathrm{~mm}, 2000 \mathrm{~m}$ távolságból $64 \mathrm{~mm}$ páncélt ütött át $30^{\circ}$-os becsapódási szög esetén. A 7,5 cm-es Gr 38 HL/C kumulatív lőszer, 2000 méter távolságból $100 \mathrm{~mm}$ páncél átütésére volt alkalmas.

$\mathrm{Az}$ alkalmazott csőszájfékre tulajdonképpen nem volt szükség, minthogy ennél a páncélosnál nem a tornyot, hanem a legerősebb homlokpáncél közvetítésével az egész páncéltestet terhelte a hátra lökés. A csőszájfék tartós tüzelésnél csak a csőhátrasiklás olajfékjét védte a túlmelegedéstől. Elhagyása, csak egyetlen problémát okozott. Az addig oldalra terelt lőporgázok most előre hagyták el a csövet, ami az irányzólövészt poros területen tüzeléskor esetenként zavarta a célzásban.
Az első 30 vadászpáncélost, amelyek a Jagdpanzer IV Ausf. F, Sd.Kfz 162 megjelölést kapták, 1944 januárjában vette át a Waffenamt (Fegyverzetügyi Hivatal).

Ezeknek az első, a korábbi páncélvadászok tűzerejét és védettségét is lényegesen meghaladó, a Pz IV-es teknőjére épített vadászpáncélosoknak kialakítása teljesen újszerü volt. Körkörösen erős páncélzatúak, pontos, nagy átütőerejü löveggel szereltek, mozgékonyak voltak, és magasságuk végső formájukban sem lépte túl az 1850 mm-t.

Már nem tipikusan lesből támadtak, adottságaik révén képesek voltak az ellenséget felkutatni, és nagyobb távolságból is megsemmisíteni.

A fejlesztésnél ügyeltek arra, hogy lehetőség szerint kevés új elemre legyen szükség, így az alapul szolgáló $\mathrm{Pz}$ IV-es páncélos minél több egységét megtartották. Ezek között a 300 LE teljesítményű HL 120TRM motort és a ZF SSG 76-os sebességváltót is az oldalsó előtét-áttételekkel, kormányfékekkel, meghajtó és a láncfeszítő kerekekkel együtt. Nem változtak a motortér burkoló páncél elemei sem.

A felépítmény körkörösen zárt, különböző szögben döntött páncéllemezekből állt.

Teljesen eltért a Pz IV-es harckocsitól a homlokpáncél ballisztikailag nagyon kedvező kialakítása. A felső, $60 \mathrm{~mm}$ vastag homlokpáncél $45^{\circ}$-ban volt döntve, ami vízszintes irányban megfelelt $110 \mathrm{~mm}$ páncélvastagságnak, az alsó, $50 \mathrm{~mm}$-es, $55^{\circ}$-ban döntött elem pedig $123 \mathrm{~mm}$-es páncéllemez védelmét nyújtotta. A küzdőteret átalakították, az üzemanyagtartályt a korábbi, torony alatti helyéről a harckocsi első részébe tették át. A Pz IV-es harckocsiknál a $\mathrm{H}$ változatig alkalmazott kéthengeres DKW motorral szerelt aggregát is elmaradt, helyére egy további üzemanyagtartály került. Így a teljes üzemanyag javadalmazás 470 literre növekedett, ami úton 210, terepen $130 \mathrm{~km}$ távolságra volt elegendő.

A vadászpáncélos személyzete 4 főből állt:

- lövegparancsnok, aki egyben a harckocsi parancsnoka is;

- irányzólövész;

- töltőkezelő;

- harckocsivezető.

A parancsnoki változat esetében a személyzet még egy rádióssal is kiegészült.

6. ábra. A kép egy L/48-as löveggel szerelt „túlélő” példányt mutat a svájci Thun harckocsi múzeumában

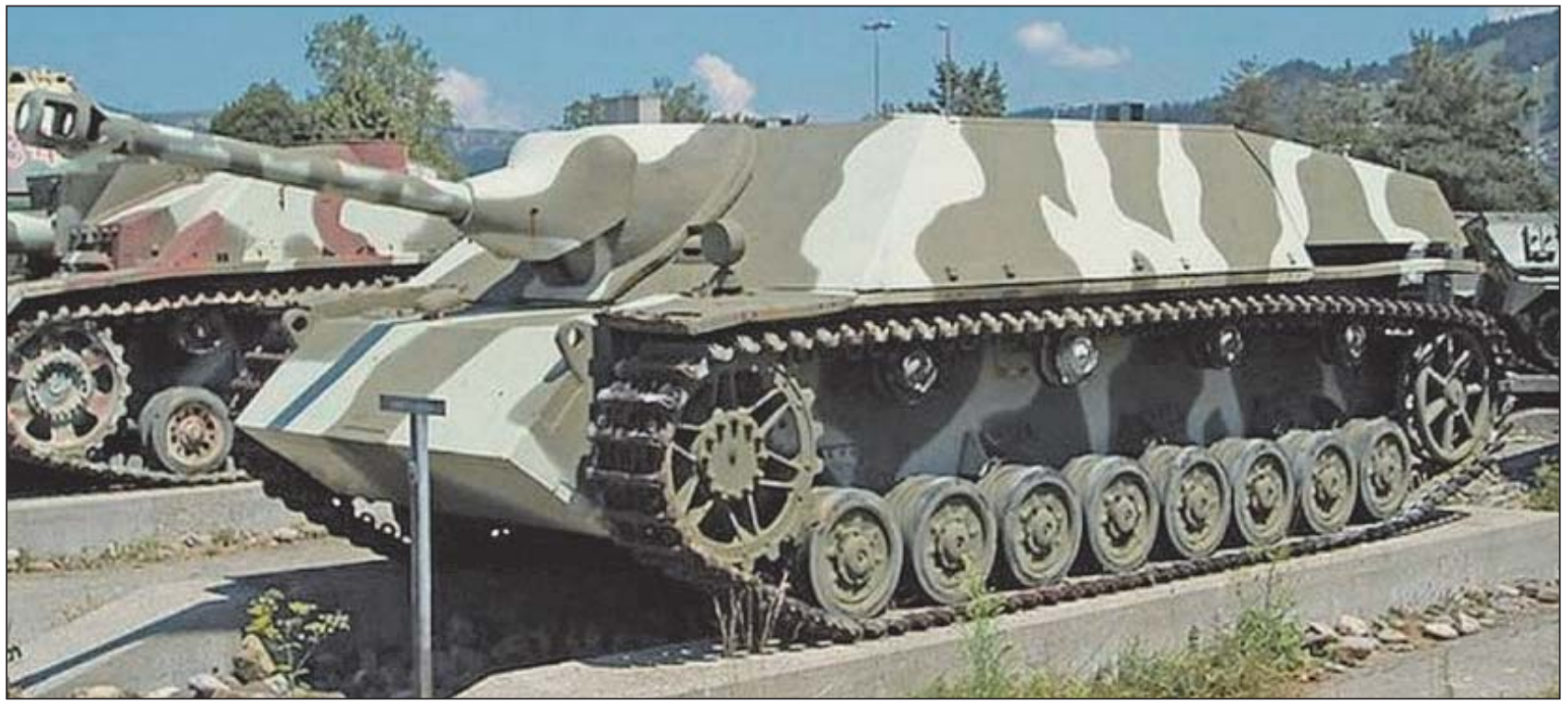




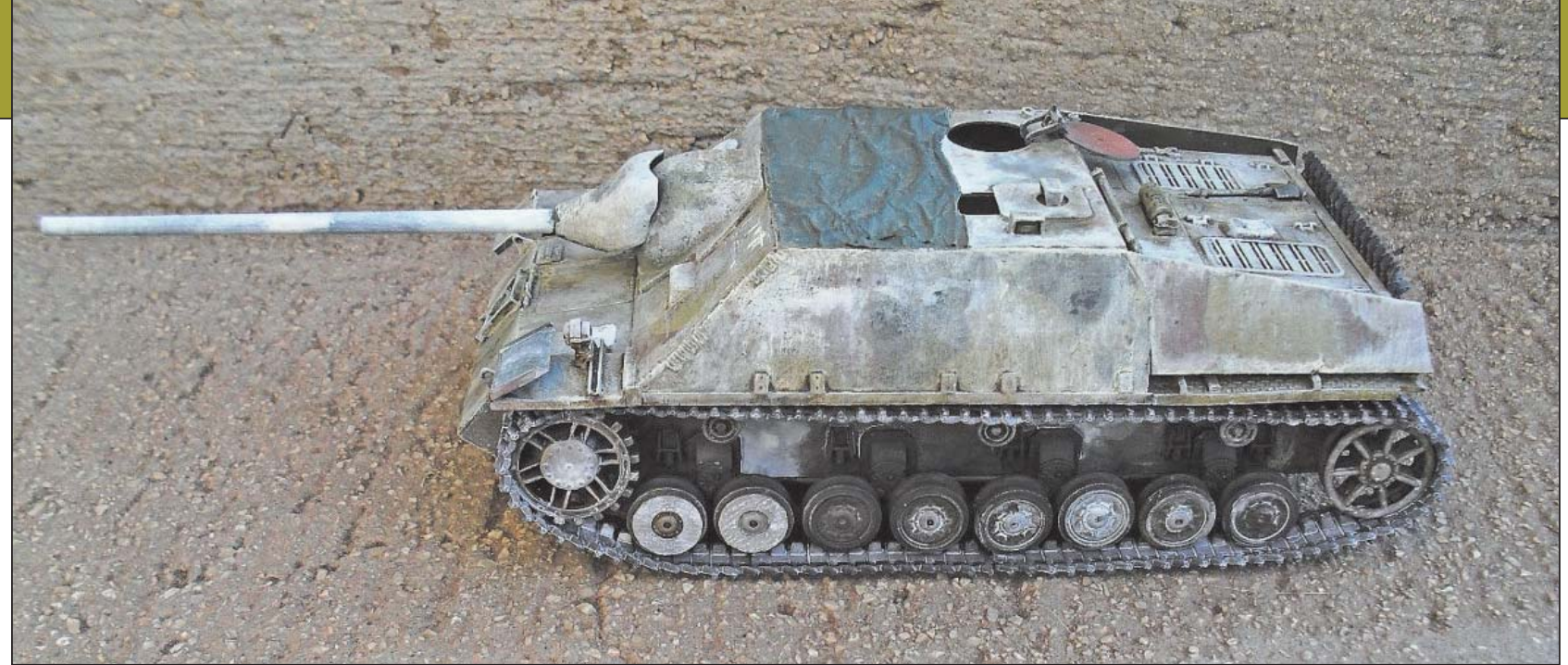

7. ábra. Késői gyártású, zimmerit nélküli, hátul vízszintes kipufogóval szerelt, a magyarországi hadszíntéren 1944/45 telén lefényképezett Jagdpanzer IV L/70 vadászpáncélos egyedi építésű 1:35-ös makettje (Makett: Tolnay Trisztán Péter)

Mint más német harckocsiknál, itt is nehéz egy standard változatról beszélni. A gyártás során folyamatosan beérkező módosítási javaslatok befolyásolták a verziót. Ezek egyrészt harcértékjavító változtatások voltak, másrészt takarékossági célokat szolgáltak.

Néhány példa ezekre a módosításokra:

Így 1944 januárjában megkezdték az ellenséges, támadó gyalogság elleni közelharc vetőszerkezet, a „Nahverteidigungswaffe" beépítését.

1944. februárban a páncélos amúgy is erősen túlterhelt homlokrészéről a motortér hátsó burkolatára helyezték át a tartalék lánctagokat és ugyancsak hátra kerültek a tartalék futógörgők is.

1944. márciusban elmaradt a homlokpáncél bal oldali géppuska nyílása. A gyártás során már kivágott nyílásokat behegesztették.

1944. áprilisban módosították (levágták) a lövegblende alsó sarkait, ezzel is csökkentve annak súlyát.

1944. májusban a 320301 alvázszámtól 80 mm-re növelték az alsó és a felső homlokpáncél vastagságát. A hónap végétől nem szereltek a lövegre csőszájféket.

1944. szeptemberben a korábbi, oldalanként 4 lánc viszszavezető-görgő helyett csak hármat szereltek a páncélosra. A csapatok részéről, a mágneses aknák elleni „zimmerit” bevonat esetleges gyulladására vonatkozó jelzések nyomán, a hónap végétől nem hordták fel a harckocsikra ezt az anyagot.

Ebből a páncélosból a gyártás 1944. novemberi megszűnéséig 769 példány készült.

Egyrészt az első vádász-páncélosokkal szerezett pozitív harctéri tapasztalatok, másrészt a frontokon fellépő ellenséges páncélosok egyre erősebb páncélzata miatt a csapatok egy erősebb löveg beépítését szorgalmazták.

\section{Panzer IV/70 (V) változat}

Már a létrehozandó új vadászpáncélossal kapcsolatos első, 1942 szeptemberi megbeszélésen is elhangzott az igény, hogy azt a 7,5 cm-es, hosszú csövű L/70-es löveggel szereljék fel. Ezt az ágyút a Panther harckocsihoz fejlesztették ki. Visszatekintve megállapítható, hogy ez a löveg a második világháború egyik legsikerültebb páncéltörő fegyvere volt. Félautomata működésű és elektromos elsütőszerkezettel szerelt. Lövés után kivetette a hüvelyt és a zár nyitva maradt.

A Jagdpanzer IV-es első változatának gyártásakor azonban még nem lehetett számolni ezzel a löveggel, ezért azokba 1944 januárjától a 7,5cm Pak 39 L/48-as ágyút építették be.

A hosszabb csövű változat alkalmazása azonban folyamatosan napirenden maradt, és ahogy a páncélvadász program rendelkezésére álltak ezek a lövegek, megkezdődtek a beépítésével kapcsolatos munkák.

A PaK 42 típusú L/70-es kaliberhosszúságú löveg a PzGr. 39-es páncéltörő lövedéket $925 \mathrm{~m} / \mathrm{s}$ torkolati sebességgel lőtte ki, amivel 500 m-en $30^{\circ}$-os becsapódási szög esetén 125, 1000 méter távolságból pedig 110 milliméter vastag páncélzat átütésére volt képes. Ezzel a teljesítménynyel minden korabeli harckocsit meg tudott semmisíteni.

Az első, ilyen löveggel felszerelt Jagdpanzer IV-est 1944 áprilisában mutatták be a Heereswaffenamt képviselőinek. Később Hitler is megtekintette a páncélost, ami olyan mély benyomást tett rá, hogy azonnal elrendelte havi - az adott körülményeket tekintve illuzorikus - 800 darab gyártását.

Ugyancsak ő határozott úgy, hogy a típus megnevezése Panzer IV lang (hosszú) $(V)$ legyen. A „V” betű a gyártó Vomag cégre utalt, amely ennek a páncélosnak kizáróla-

8. ábra. Jól látható a páncéltesthez viszonyítva is hosszú L/70-es lövegcső

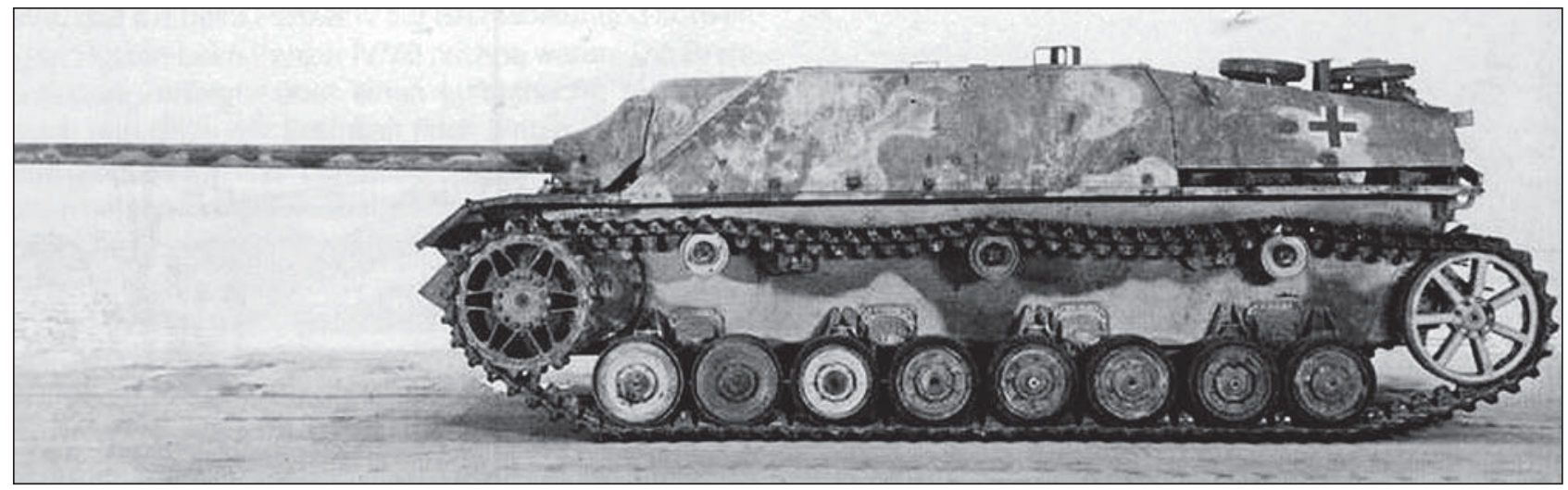




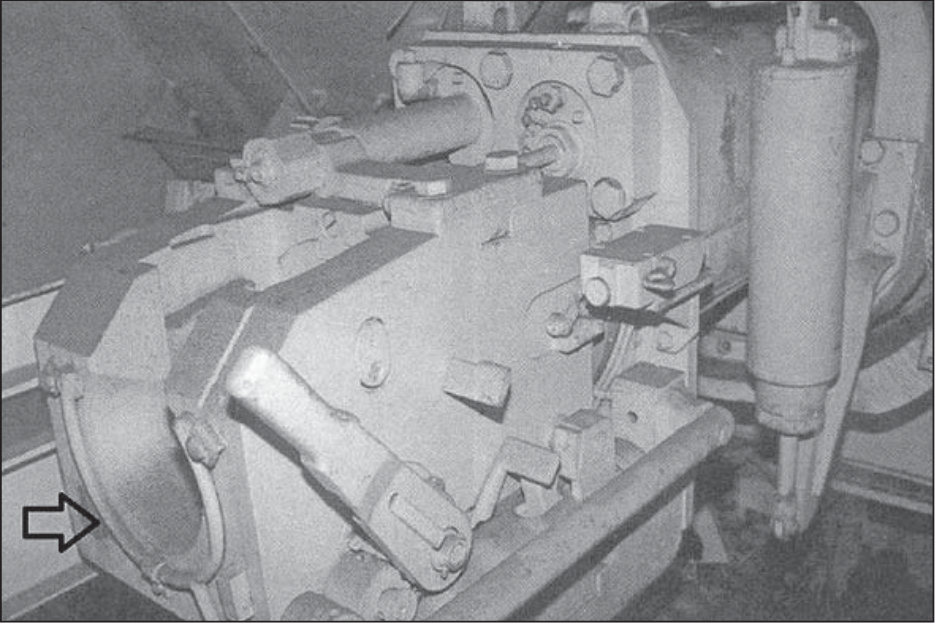

9. ábra. A páncélosba beépített L/70-es löveg zárszerkezete, rajta a csőkifúvó légvezetékével (nyíl)

gos gyártója volt. A csapatok azonban a Panzer IV/70 (V) megjelölést használták, ami 1944 novemberétől hivatalosan is a típus neve lett.

Az új löveg beépítéséhez számtalan módosítást kellett elvégezni a vadászpáncéloson

A hosszabb ágyú nagyobb súlya miatt szükséges volt a külső és belső lövegblende módosítása úgy, hogy a páncélvédettség ne csökkenjen. Azért, hogy a terepen, egyenetlen úton haladva nehéz lövegcső lengése és az ebből adódó gyakori „jusztírozás” elkerülhető legyen, egy csőtámaszt építettek a harckocsi vízszintes homlokpáncéljára. A rövidcsövű változatnál alkalmazott küzdőtér szellőző ventilátora helyett csőkifúvót használtak, amely a lőporgázokat a lövés leadása után azonnal eltávolította a csőből. A nagyobb teljesítményű, így más méretű lőszerek a korábbi tárolóhelyek átalakítását is szükségessé tették. Ezekből 60 darab számára volt hely a páncélosban.

Már a rövidebb löveggel szerelt vadászpáncélos változat is „fejnehéz” volt, a hosszú, nagyobb súlyú ágyú miatt e probléma ezt követően fokozottabban jelentkezett. A megoldás keresése közben Hitler a homlokpáncél vastagságának kényszerből csökkentését is megparancsolta, ezt azonban nem hajtották végre. A futómú átépítése nem volt lehetséges, így egyetlen változtatás a két (majd később még két) első görgős kocsi futókerekeinek - a szovjet KV I páncélostól átvett - egészen kevés gumi alkalmazásával kialakított, nagyobb teherbírású acél görgőkre cserélése volt.

A gyártás során ezt a módosítást, és egy könnyebb tagokból álló lánctalp bevezetését 1944 szeptemberében hajtották végre.

Több más változtatással együtt, az 1944 novemberétől gyártott páncélosokon elmaradtak a két első fék karbantartó nyílás szellőző fülei. Ettől az időponttól kezdve a fékszellőzés és a fékpor elszívása hosszabb csatornán keresztül, a motortér hütőventilátorra való csatlakoztatásával történt.

A páncélosok egy részét $5 \mathrm{~mm}$-es fém „kötényzettel” látták el, ami a kisebb kaliberű páncéltörő fegyverek és a kumulatív lövedékek ellen nyújtott kiegészítő védelmet.

A Vomag az első 57 darab hosszú csövű vadászpáncélost 1944 augusztusában szállította le. Ettől az időponttól kezdve az anyagellátás és a háború okozta más akadályok függvényében ingadozó darabszámmal folyt a gyártás.

A szövetségesek 1945. márciusi, Plauen ellen intézett három súlyos bombatámadása nyomán, a gyártás - 930 Panzer IV/70 (V) vadászpáncélos kiszállítása után - megszűnt.

\section{JagdPanZER IV L/70 (A) VÁLtOZAT}

A Pz IV-es teknőjének, valamint a 75 mm-es L/70-es páncéltörő lövegnek a felhasználásával készült egy harmadik páncélvadász változat is.

A két másik páncélvadász gyártására folyamatos átállással a Vomagnál megszüntették az alaptípus Pz IV-es gyártását. Az ausztriai St. Valentinben működő Nibelungwerkenben azonban még 1944 nyarán is folytatódott a IV-es típusú harckocsi gyártása.

Adva volt tehát a páncélos teknője, amelynek felhasználásával további, a front által követelt, L/70-es löveggel szerelt vadászpáncélosokat lehetett gyártani.

A Heereswaffenamt hadmérnökei előtt nyilvánvaló volt, hogy a háború e késői szakaszában a Pz IV-es bármelyik változatát már minden tekintetben felülmúlják a szovjet T34/85-ös és a JS 122-es páncélosok. Ezért egyedüli megoldásnak azt látták, hogy a Pz IV/70-es bevált felépítményét ráépítik a harcértékben túlhaladott Pz IV-es teknőjére. A kísérleti példánnyal végzett próbák azt is megmutatták, hogy ez a „StuG mit 7,5 cm KwK 42 L/70” (rohamlöveg 7,5 cm-es L/70 42 harckocsiágyúval) a siker reményében veheti fel a harcot minden front valamennyi ellenséges harckocsijával.

Ennél a páncélosnál valójában egy szükségmegoldásról volt szó.

A két másik, ugyancsak Pz IV-es páncélteknőre épített változattól eltérően, a felhasznált harckocsiteknőn itt nem alakították ki a ballisztikailag kedvező, erős homlokpáncélzatot, de a többi belső átalakítást is csak annyiban végezték el, amennyire a nagyobb löveg működtetéséhez az feltétlenül szükséges volt.

A németek számára kényszerü háborús helyzetben azonban, ahol azonnal és minél nagyobb számú páncélosra volt szükség, inkább vállalták az alacsony páncélvédettséget és a másik páncélvadásznál közel $30 \mathrm{~cm}$-rel magasabb felépítményt, mindezt azonban összekapcsolva a nagyon hatásos löveggel.

A „fejnehéz" felépítmény miatt néhány átalakítást itt is el kellett végezni. A futómű első két (később négy) görgős kocsijának kerekeit ugyancsak az erősített kivitelüre cserélték. A lánc visszavezető görgőinek számát csökkentették, az először alkalmazott 5 mm-es fémkötényeket könnyebb, praktikusabb és olcsóbb dróthálóra („Thoma-Schild”) cserélték.

A gyártás teljes ideje alatt a tervezett 150 példányt meszsze túllépve, 278 ilyen páncélos készült.

A harckocsikat a gyártás során sötétsárga (RAL7028) színre festették, amelyet azután a csapatoknál a mindenkori célszerüségnek megfelelően és az adottságok függvényében sötétbarna (RAL8017), vagy olívzöld (RAL6003) álcázó színnel egészítettek ki. A téli álcázó szín a szürkésfehér (RAL9002) volt.

\section{AlKalmazÁsuK}

A felsorolt, és jobbára kedvező műszaki adatok azonban a valós harcértéknek csak egyik összetevőjét jelentették. A háború során az egyre nagyobb személyi veszteségek értelemszerűen a még jó kiképzést kapott, gyakorlott személyzetet érintették. A később ki- és átképzett harckocsizók egyre gyakrabban kerültek túl hamar bevetésre, tapasztatlanságukat a vadászpáncélos konstrukciója nem tudta minden tekintetben kiegyenlíteni. A háború előre haladtával egyre nehezebb üzemanyag- és alkatrészhiány ugyancsak megnehezítette a vadászpáncélosok sikeres alkalmazását. 


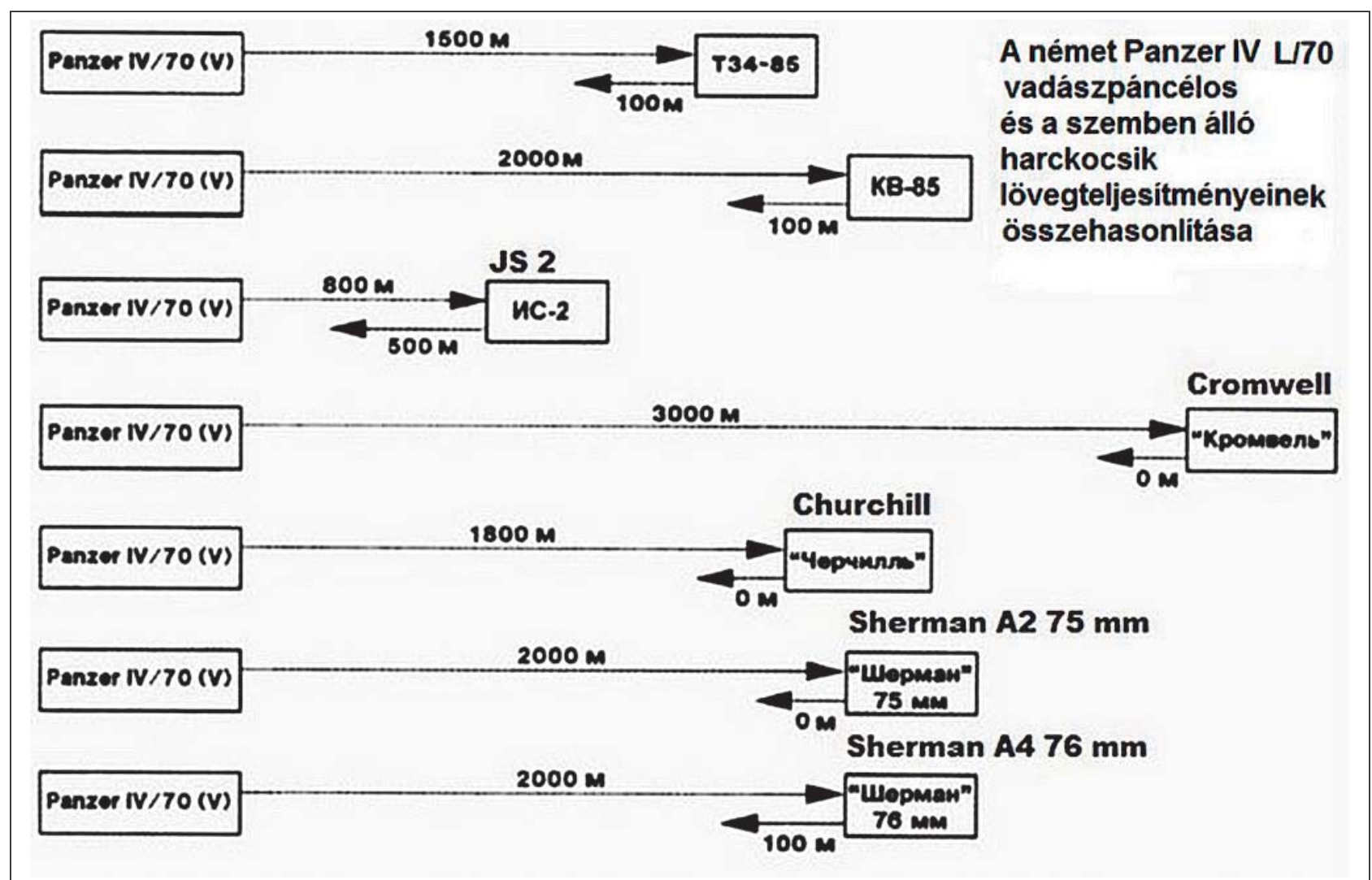

10. ábra. Az L/70-es, és potenciális ellenfeleinek löveg-átütőképességeit szemléltető rajz (Forrás: Vojenno-tehnicseszkaja szerija, Nr. 160. Jagdpanzer IV L/70, Moszkva, a Spielberger-Doyle-Jentz: Leichte Jagdpanzer, Motorbuch Verlag 1992. alapján) ${ }^{1}$

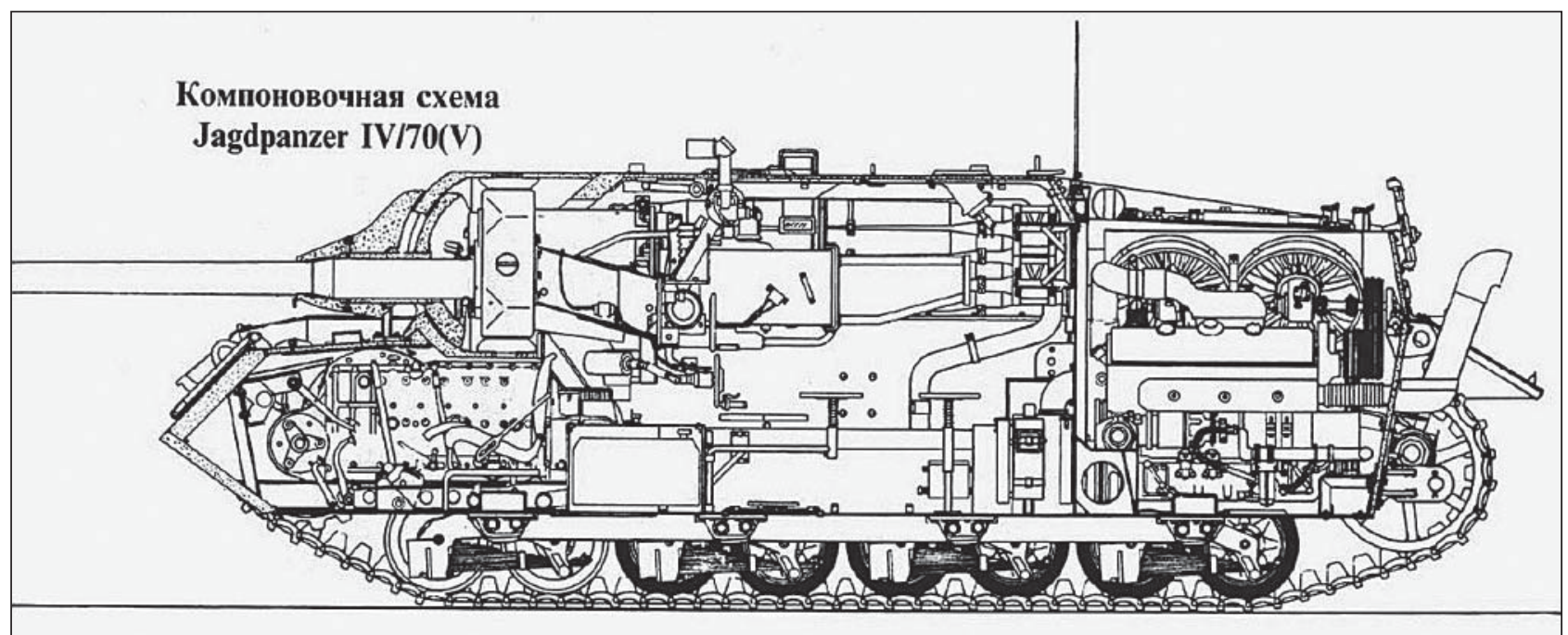

11. ábra. Az L/70-es változat metszeti rajza

A Jagdpanzer IV-eseket 1944 márciusától a páncélos és a páncélgránátos hadosztályok páncélvadász-zászlóaljaiba osztották be. Minden páncélvadász-század a szervezeti táblával egyezően tíz, vagy tizennégy Jagdpanzer IV-est kapott. Általában a páncélos hadosztályok páncélvadászzászlóaljai két, 10-10 páncélosból álló századból álltak, amelyet kiegészített a zászlóaljparancsnok Pz IV-es harckocsija.

A páncélgránátos hadosztályok páncélvadász-zászlóaljai két, egyenként 14 Jagdpanzer IV-sel felszerelt századból álltak, amelyeket kiegészített három további Jagd- panzer IV-es harckocsi, amelyek a zászlóalj-törzs páncélosai voltak.

A rövid csövű (L/48-as) vadászpáncélosok első bevetésére 1944 márciusában, Olaszországban került sor, a Herman Göring ejtőernyős hadosztály páncélvadász zászlóaljainál.

A Panzer IV/70(V) páncélosok a nyugati fronton először, a 106. páncélos dandár kötelékében vették fel a harcot a támadó szövetségesekkel.

A normandiai invázió után 1944 júniusában a PanzerLehr és a Hitlerjugend hadosztályok harcoltak - más pán- 
1. táblázat. A PZ IV. vadászpáncélosok változatai

\begin{tabular}{|c|c|c|c|}
\hline Gyártó & Vomag & Vomag & Alkett \\
\hline Modell megnevezése & Jagdpanzer IV L/48 & Panzer IV/70 (V) & Panzer IV/70 (A) \\
\hline Wehrmacht jelölése & Sd.Kfz.162 & Sd.Kfz.162 & Sd.Kfz.162/1 \\
\hline Gyártás ideje & 1944 & 1944.08.-1945.03. & 1944.08.-1945.03. \\
\hline Motor & Maybach HL 120 TRM & Maybach HL 120 TRM & Maybach HL 120 TRM \\
\hline Motor fajtája & benzinmotor, V-12 & benzinmotor, V-12 & benzinmotor, V-12 \\
\hline Motor LE teljesítmény/ford./min & $300 / 3000$ & $300 / 3000$ & 300/3000 (TR 120 320) \\
\hline Lökettérfogat $\left(\mathrm{cm}^{3}\right)$ & 11867 & 11867 & 11867 \\
\hline Furat/löket & $105 / 115$ & $105 / 115$ & $105 / 115$ \\
\hline Hűtés módja & folyadékhűtés & folyadékhűtés & folyadékhűtés \\
\hline Sebességváltó & Aphon ZF SSG 76 & Aphon ZF SSG 76 & Aphon ZF SSG 76 \\
\hline Sebességfokozatok & $6+1$ & $6+1$ & $6+1$ \\
\hline Max. sebesség, (km/h) & 40 & 37 & 39 \\
\hline $\begin{array}{l}\text { Üzemanyag-fogyasztás úton/ } \\
\text { terepen (liter) }\end{array}$ & $220 / 360$ & $220 / 360$ & $200 / 400$ \\
\hline Üzemanyagtartály (liter) & 470 & 470 & $?$ \\
\hline Hatósugár úton/terepen (km) & $210 / 130$ & $210 / 130$ & $200 / 130$ \\
\hline Ütközeti súly (kg) & 24000 & 25800 & 27000 \\
\hline Méretek $h^{\star} \times s z \times m(m m)$ & $6850 \times 3170 \times 1850$ & $8500 \times 3170 \times 1850$ & $8870 \times 2900 \times 2200$ \\
\hline Tűzmagasság (mm) & 1400 & 1400 & 1800 \\
\hline Szabad hasmagasság (mm) & 400 & 400 & 400 \\
\hline Gázlóképesség (mm) & 1000 & 1550 & 1200 \\
\hline Lejtőmászó képesség & $30^{\circ}$ & $30^{\circ}$ & $30^{\circ}$ \\
\hline Árok-áthidaló képesség & $2200 \mathrm{~mm}$ & $2200 \mathrm{~mm}$ & $2200 \mathrm{~mm}$ \\
\hline Lépcsőmászó képesség & $600 \mathrm{~mm}$ & $600 \mathrm{~mm}$ & $600 \mathrm{~mm}$ \\
\hline Személyzet & $\begin{array}{c}4 \text { fő } \\
\text { (parancsnoki } 5 \text { fö) }\end{array}$ & $\begin{array}{c}4 \text { fö } \\
\text { (parancsnoki } 5 \text { fö) }\end{array}$ & $\begin{array}{c}4 \text { fő } \\
\text { (parancsnoki } 5 \text { fö) }\end{array}$ \\
\hline Fő fegyverzet & 7,5 cm Pak 39 L/48 & 7,5 cm Pak 42 L/70 & $7,5 \mathrm{~cm}$ Pak $42 \mathrm{~L} / 70$ \\
\hline Függőleges irányzás & $-8^{\circ}-+15^{\circ}$ & $-6^{\circ}-+15^{\circ}$ & $-6^{\circ}-+15^{\circ}$ \\
\hline Oldalirányú irányzás & jobbra $15^{\circ}$ balra $12^{\circ}$ & jobbra/balra $12^{\circ}$ & jobbra/balra $12^{\circ}$ \\
\hline Lőszer-javadalmazás (löveg) & $\begin{array}{l}\text { 79×7,5 cm repeszgr. + } \\
\text { + páncélgr. }\end{array}$ & $\begin{array}{c}60 \times 7,5 \mathrm{~cm} \text { repeszgr. + } \\
+ \text { páncélgr. }\end{array}$ & $\begin{array}{l}90 \times 7,5 \text { cm repeszgr. + } \\
\text { + páncélgr. }\end{array}$ \\
\hline
\end{tabular}

* Hosszúság lövegcsővel

célosok mellett - mintegy 60 db Jagdpanzer IV-es harckocsival, a partra szállt alakulatok ellen.

Legnagyobb darabszámú egyidejü, közel 130 db Panzer IV/70 (V) bevetésére az Ardennekben került sor, 1944-ben.

A keleti fronton a 4. és az 5. páncéloshadosztályok alkalmazták először jobbára az L/70-es változatot, ahol 1944 szeptemberétől kerültek az ott harcoló alakulatokhoz, részben a rohamlöveg veszteségeik pótlására.

Egy hónappal a háború vége előtt még 285 Panzer IV-es vadászpáncélos állt harcban, 274 a keleti, a többi a nyugati és az olasz fronton.

E páncélvadászról - különösen a két első változatáról - elmondható, hogy sikeres konstrukciónak bizonyultak. A döntött, erős páncélzat és az alacsony felépítés nagyon jó védelmet biztosított az erősebb fegyverzetű ellenséges harckocsik lövegeivel szemben is. Ezekbe a német harckocsikba épített ágyúk - főképpen az L/70-es - a páncélvadászt alkalmassá tették bármely ellenséges harckocsival való harcra. Mint a táblázat is mutatja, még az akkori legerősebb löveggel felszerelt szovjet JS 122-es páncélost is nagyobb távolságból volt képes szemből megsemmisíteni, mint az át tudta volna ütni a Jagdpanzer IV-es homlokpáncélját.

A Magyarországon 1944/45-ben folytatott harcokban a vadászpáncélos mindhárom változata részt vett.

Áll ez Budapest ostromára is. A „budapesti katlanban” maradt, hosszú csövük miatt városi körülmények között nehezebben alkalmazható harckocsik a Feldherrnhalle és a 13. páncélos hadosztály páncélosai voltak. A bekerített városrészekből a németek a védekező harcok során ezeket Budán, a Várhegy által a pesti oldalról érkező tüzérségi 
